\title{
COMPLICATIONS OF THE ANTERIOR APPROACH TO THE CERVICAL SPINE
}

\author{
COMPLICAÇÕES DO ACESSO ANTERIOR À COLUNA CERVICAL
}

\author{
COMPLICACIONES DE ACCESO A LA COLUMNA CERVICAL ANTERIOR
}

Marcelo lemos Vieira da Cunha ${ }^{1}$ Francisco Alves de Araújo Júnior², Cássio Czottis Grapiglia², Denildo César Amaral Veríssimo³,

Roberta Rehder ${ }^{3}$, Samir Ale Bark ${ }^{3}$, Luis Alencar Biurrum Borba ${ }^{3}$

\begin{abstract}
Objective: To evaluate the complications of anterior approach to the cervical spine in patients who underwent cervical arthrodesis with instrumentation. Methods: Prospective and descriptive study was conducted from January 2009 to April 2010. All patients who underwent arthrodesis of the cervical spine by anterior approach were included, regardless the diagnosis. Access was made by the anterior approach on the right side. We evaluated the number of operated levels (1, 2 or 3 levels) and, the type of procedure performed: discectomy and placement of cage and plate $(D+C+P)$, discectomy with placement of a cage $(D+C)$ or corpectomy with placement of cage and plate $(\mathrm{C}+\mathrm{C}+\mathrm{P})$. All complications related to surgical approach were reported. Results: We studied 34 patients, $70 \%$ male. The average age was 50 years and mean follow-up was 8 months. Eighteen percent of patients had complications, distributed as follows: dysphasia (33\%) and dysphonic (67\%). Among patients who developed complications, most underwent to $\mathrm{D}+\mathrm{C}+\mathrm{P}(83 \%)$ and no complications were found in patients where no cervical plate was used. Regarding levels, both complications were identified in patients operated to one or two levels. However, in patients operated on three levels, only dysphonia was identified. Conclusion: The most frequent complication was dysphonia. Patients who presented more complications were those undergoing discectomy and fusion with cage and anterior cervical plate. All cases of dysphonia were in this group. The number of accessible levels does not seem to have affected the incidence of complications.
\end{abstract}

Keywords: Spine; Deglutition disorders; Dysphonia; Arthrodesis; Patients.

\begin{abstract}
RESUMO
Objetivo: Avaliar as complicações do acesso anterior à coluna cervical em pacientes submetidos à artrodese cervical com instrumentação. Métodos: Estudo prospectivo e descritivo realizado no período de janeiro/2009 a abril/2010. Todos os pacientes submetidos à artrodese de coluna cervical por via anterior foram incluídos no estudo, independentemente do diagnóstico. O acesso foi realizado pela via anterior no lado direito. Foi avaliado o número de níveis operados (1, 2 ou 3 níveis) e o tipo de procedimento realizado: discectomia com colocação de cage e placa ( $D+C+P$ ), discectomia com colocação de cage $(D+C)$ ou corpectomia com colocação de cage e placa $(C+C+P)$. Todas as complicações relacionadas ao acesso cirúrgico foram relatadas. Resultados: Foram estudados 34 pacientes, sendo $70 \%$ do sexo masculino. A média de idade foi de 50 anos e o tempo de seguimento médio foi de oito meses. Dezoito por cento dos pacientes apresentaram complicações assim distribuídas: disfagia (33\%) e disfonia (67\%). Dentre os pacientes que evoluíram com complicações, a maioria foi submetida à realização de $D+C+P$ (83\%) e nenhuma complicação foi encontrada nos pacientes nos quais não foram colocadas placas cenvicais. Com relação aos níveis, ambas as complicações foram identificadas nos pacientes operados em um ou dois níveis. Já nos operados em três níveis, somente a disfonia foi identificada. Conclusão: A complicação mais encontrada foi a disfonia. Os pacientes que mais apresentaram complicações foram os submetidos à discectomia e artrodese com cage e placa cervical anterior. Todos os casos de disfonia estavam neste grupo. O número de níveis acessados não parece ter interferido na incidência das complicações.
\end{abstract}

Descritores: Coluna vertebral; Transtornos de deglutição; Disfonia; Artrodese; Pacientes.

\section{RESUMEN}

Objetivo: Evaluar las complicaciones del acceso anterior a la columna cervical en pacientes sometidos a artrodesis cervical con instrumentación Métodos: Estudio prospectivo y descriptivo realizado en el período de Enero/2009 hasta Abril/2010. Todos los pacientes sometidos a artrodesis de la columna cenical por vía anterior fueron incluidos en el estudio, independientemente del diagnóstico. El acceso fue realizado por vía anterior, por el lado derecho. Fueron evaluados el número de niveles operados (1, 2 o 3 niveles) y el tipo de procedimiento realizado: discectomía con colocación de cage y placa $(D+C+P)$, discectomía con colocación de cage $(D+C)$, o corpectomía con colocación de cage y placa $(C+C+P)$. Se informaron todas las complicaciones relacionadas con el acceso quirúrgico. Resultados: Fueron estudiados 34 pacientes, siendo $70 \%$ del sexo masculino. El promedio de edad fue de 50 años y el tiempo promedio de seguimiento fue de ocho meses. Dieciocho por ciento de los pacientes tuvieron complicaciones distribuidas de la siguiente manera: disfagia (33\%) y disfonía (67\%). De los paciente que desarrollaron complicaciones, la mayoría fue sometida a la realización de $D+C+P(83 \%)$ y ninguna complicación fue relacionada con las técnicas que no utilizaron placas cervicales. Con relación a los niveles, las dos complicaciones fueron identificadas en los pacientes operados en uno o dos niveles. Sin embargo, en los operados en três niveles, sólo fue identificada la disfonía. Conclusión: La complicación más frecuente fue la disfonía. Los pacientes que más presentaron complicaciones fueron aquellos sometidos a discectomía y artrodesis con cage y placa cervical anterior. Todos los casos de disfonía estaban en este grupo. El número de niveles operados no parece haber afectado a la incidencia de complicaciones.

Descriptores: Columna vertebral; Trastornos de deglución; Disfonía; Artrodesis; Pacientes.

1. Department of Neurosurgery of the Hospital Regional do Oeste, Chapecó, SC, Brazil.

2. Department of Neurosurgery of the Hospital Nossa Senhora do Rocio, Campo Largo, PR, Brazil.

3. Department of Neurosurgery of Hospital Universitário Evangélico de Curitiba (HUEC), Curitiba, PR, Brazil.

Study conducted at the Hospital Universitário Evangélico de Curitiba (HUEC), Curitiba, PR, Brazil.

Correspondence: Rua Rui Barbosa, 93 E, Chapecó, SC, Brasil. 89801-040. marcelolvc@yahoo.com.br 


\section{INTRODUCTION}

The anterior approach to the cervical spine can be used as surgical treatment for various diseases, including fractures, degenerative disease, neoplasia, and correction of kyphotic deformities, among others. ${ }^{1}$

During the surgical procedure, several structures must be dissected and retracted in order to properly expose the cervical spine. These include the anterior neck muscles, the trachea, the esophagus, and the carotid triangle, among others., ${ }^{1,2}$

Studies have demonstrated the importance of knowledge of the recurrent laryngeal nerve $(R L N)$ in the anterior approach to the cervical spine. ${ }^{2,3}$ Injury to this nerve, by stretching or section, can lead to dysphonia. ${ }^{2-5}$ Some authors suggest that there is a greater risk of injury when the approach is performed from the right side, ${ }^{2}$ but others have shown that the side of the approach is not correlated with the possibility of nerve injury. ${ }^{3}$ Retraction of the esophagus is associated with dysphagia, and there are also reports of esophageal perforation as a complication of this approach. 4,6,7

The placement of an anterior cervical plate appears to increase surgical time, and can lead to greater damage to the tissue of the retracted structures. It is, therefore, a factor that can contribute to postoperative complications. However, it is used to promote faster arthrodesis and enable earlier recovery. ${ }^{8}$

Thus, it is important to have data that can suggest factors that lead to these complications. The objective of this study was to evaluate the postoperative complications of the anterior approach to the cervical spine in patients who underwent arthrodesis with instrumentation.

\section{METHODS}

This is a prospective, cross-sectional study conducted by the Department of Neurosurgery of the Hospital Universitário Evangélico de Curitiba, Paraná, Brazil, during the period January 2009 to April 2010.

The patients included in the study were all those submitted to anterior approach cervical fusion, regardless of the diagnosis of the disease. Preoperative exams included imaging exams of the cervical spine (x-rays, computed tomography, and magnetic resonance imaging).

A prophylactic antibiotic was administered with the anesthesia. The patients were intubated in the conventional way, seeking to keep the neck immobile.

The skin incision was performed obliquely following the neck line when visible. The anatomical points of reference were used to identify the level to be operated, which was confirmed intraoperatively with a fluoroscope. All the procedures were performed from the left side, by teaching neurosurgeons or supervised senior residents. The procedures performed were: 1) discectomy plus placement of an intersomatic device plus anterior cervical plate $(D+P+P) ; 2)$ discectomy plus placement of an intersomatic device (D+P); and 3 ) corpectomy plus placement of an intersomatic device plus anterior cervical plate $(C+P+P)$. In all cases, the intersomatic device used was a titanium cage filled with autologous bone graft. A suction drain was left in all patients and removed after 24 hours.

In the immediate postoperative period, patients remained hospitalized for approximately 24 hours in the intensive care unit. Control X-rays of the cervical spine were taken prior to discharge.

The average follow-up period was eight months (1 month to 15 months)

All complications related to the procedure were observed and analyzed.

The data was organized in tables and analyzed descriptively.

\section{RESULTS}

A total of 34 patients underwent surgical treatment; 24 (70.5\%) males and 10 (29.5\%) females. Their average age was 50 years, ranging from 29 to 73 years. The average follow-up time was eight months (ranging from 1 to 15 months).
The diagnoses included degenerative spine disease $(71 \%-24$ patients), traumatic cervical spinal cord injury (23\% - eight patients), and tumor of the cervical spine (6\% - two patients).

Most of the patients (65\%) underwent surgery at a single level. The most commonly performed procedure was the $\mathrm{D}+\mathrm{P}+\mathrm{P}(71 \%)$. $D+P+P$ was performed in all the patients who underwent fusion of three levels. Three patients $(37.5 \%)$ underwent corpectomies of a single level, which is considered to be fusion of two levels.

Six patients (18\% of the cases) had complications related to the surgical approach. (Figure 1)

The complications were dysphagia and dysphonia, the latter being more commonly encountered (67\%). (Figure 2)

The number of complications occurring by groups of patients with fusion of 1, 2, and 3 levels were similar. (Figure 3)

Most of the patients who developed complications were those who underwent discectomy using a cage and cervical plate for fusion $(D+P+P)$. In those in whom a cervical plate was not used $(D+P)$, no complications were identified. (Figure 4)

In relation to the number of fused levels, (Figure 5) dysphonia was the most common among patients who underwent fusion of three levels, and was also the only complication found in this group. The numbers of instances of dysphagia and dysphonia in the groups with fusion of either one or two levels were similar.

Taking the type of procedure performed into account, (Figure 6) the placement of the plate $(D+P+P)$ presented both types of complications cited above. All the cases of dysphonia also occurred in this group. In the patients who underwent corpectomy, only one complication was reported; that of a patient who developed dysphagia. There were no complications related to the surgical approach in the group of patients where the cervical plate was not used $(D+P)$.

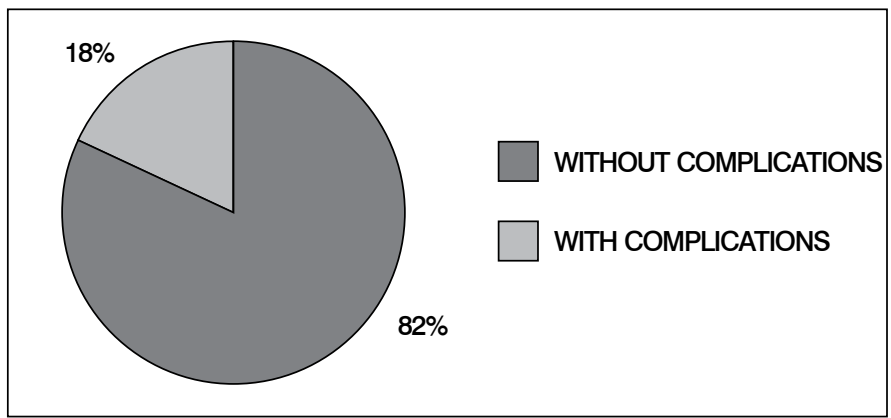

Figure 1. Percentage of patients who presented complications.

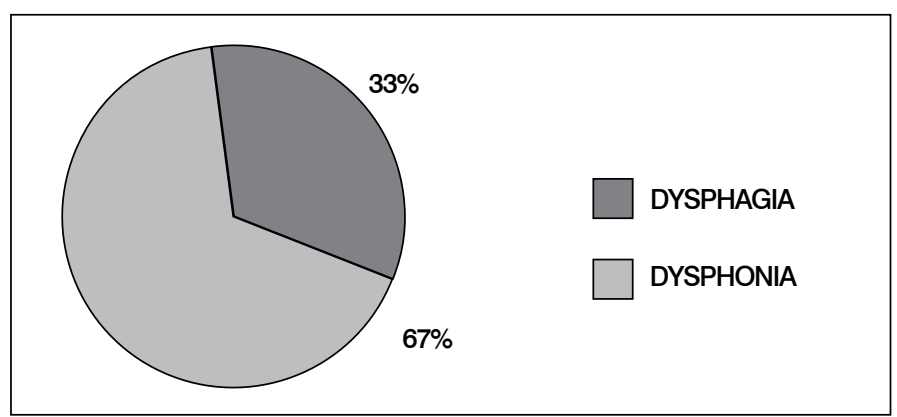

Figure 2. Percentage of complications.

\section{DISCUSSION}

Anterior approach cervical fusion is a widely used surgical technique for the treatment of various comorbidities that affect the cervical spine. ${ }^{1}$ The different types of complications that can result from an anterior approach to the cervical spine include vascular, esophageal, and tracheal damage, infection, and injury to the recurrent laryngeal nerve. ${ }^{3-5,9,10}$ 


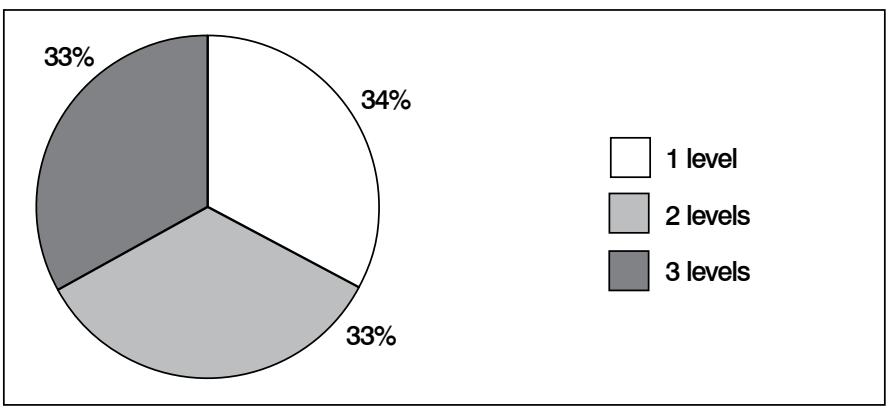

Figure 3. Percentage of complications by number of levels operated.

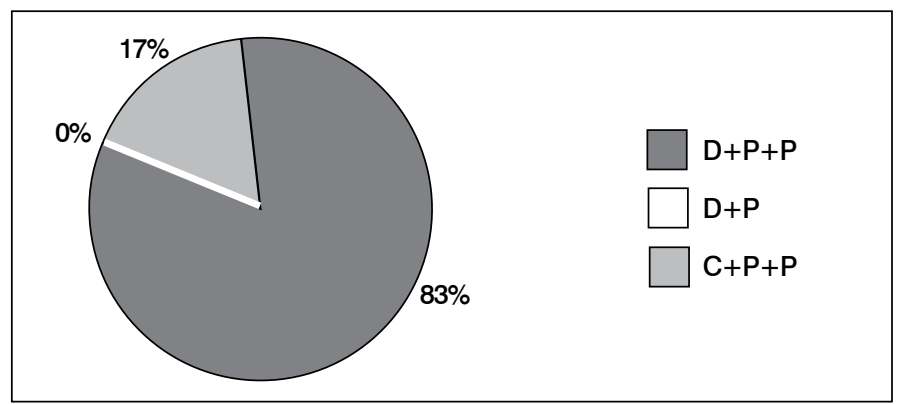

Figure 4. Percentage of complications by type of procedure performed.

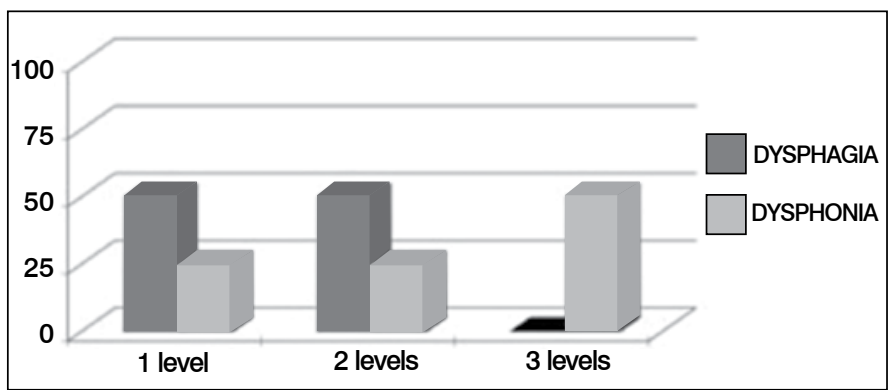

Figure 5. Percentage of complications by number of levels operated.

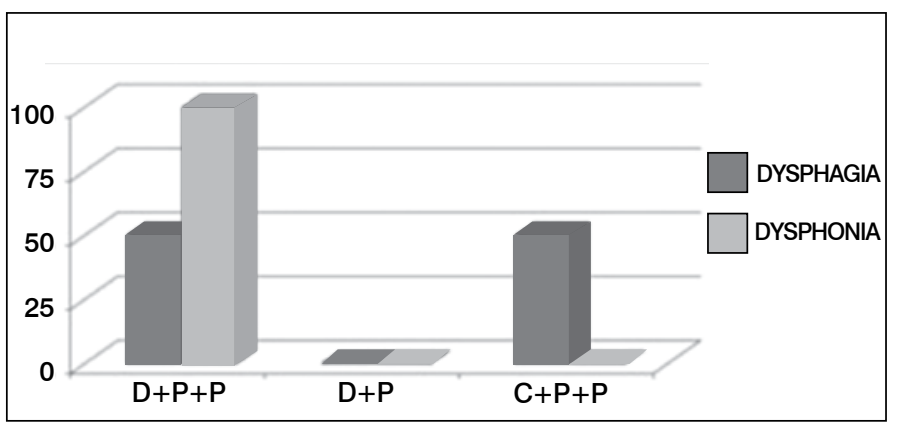

Figure 6. Percentage of complications by type of procedure performed.
Dysphonia is the result of damage to this nerve which can be caused not only by section of the nerve, but also by stretching during retraction of the muscle from the vertebra. Arantes et a ${ }^{2}$ suggest that the RLN is more susceptible to injury when access is from the right side, because of the anatomy of the nerve. Kilburg et a ${ }^{3}$ studied 418 patients who underwent anterior cervical fusion of one or two levels, and found RLN injuries in $1.9 \%$ of cases, with no statistically significant difference between the sides of approach.

In our study, only six patients had complications related to surgical access and these were only dysphonia and dysphagia. Dysphonia was the more common complication among these six cases $(67 \%)$ and all of the patients underwent an approach from the right side.

Dysphagia can be caused by the excessive retraction of the esophagus and larynx resulting in swelling and, later, possibly presenting areas of fibrosis. ${ }^{4,9}$ Dysphagia can also be caused by the displacement of the fixation plate and the screws.

In our study, dysphagia was only found in patients with placement of a plate and screws, but displacement of this material was not observed in any of these patients, suggesting that the mere presence of the plate and screws can cause symptoms. Another important factor is that for placement of the plate and screw, the esophagus and the larynx remain moved to the side and/or retracted for a longer period of time, leaving the patient more susceptible to postoperative dysphagia.

However, when the number of levels operated is considered, dysphagia was not observed in patients with surgery to three levels. Bazaz et a ${ }^{1}$ evaluated the incidence of dysphagia in patients who underwent anterior cervical fusion and showed that there was no relationship between the postoperative presence of dysphagia and the number of levels treated or the type of procedure performed. Jagannathan et a $l^{10}$ observed dysphagia in $9 \%$ of their patients who underwent anterior cervical discectomy of only one level without the use of a plate.

Both complications were temporary and 14 days following the surgery, when the patients returned to the clinic for reevaluation, none of them reported any symptoms.

The complications encountered do not appear to be associated with the number of levels treated, but they do seem to be related to the use of anterior fixation material (plate and screw). Randomized studies with larger samples need to be conducted to evaluate the real impact of these variables in complications resulting from an anterior approach to the cervical spine.

\section{CONCLUSION}

The most common complication was dysphonia. The patients who presented the most complications were those who underwent arthrodesis with discectomy using a cage and an anterior cervical plate. The number of levels does not seem to impact the incidence of complications, but in patients who underwent fusion of three levels, dysphonia was the only complication.

All authors declare no potential conflict of interest concerning this article.

\section{REFERENCES}

1. Sonntag VK, Han PP, Vishteh AG. Anterior cervical discectomy. Neurosurgery. 2001;49(4):909-12

2. Arantes $A$, Gusmão $S$, Rubinstein $F$, Oliveira R. Microsurgical anatomy of the recurrent laryngeal nerve: applications on the anterior approach to the cervical spine. Arq Neuropsiquiatr. 2004;62(3A):707-10

3. Kilburg C, Sullivan HG, Mathiason MA. Effect of approach side during anterior cervical discectomy and fusion on the incidence of recurrent laryngeal nerve injury. J Neurosurg Spine. 2006:4(4):273-7.

4. Falavigna A, Righesso Neto O, Ferraz FA, Martinato G, Riegel RE. Dysphagia in patients undergoing anterior cervical surgery]. Arq Neuropsiquiatr. 2004;62(2B):499-502.

5. Bulger RF, Rejowski JE, Beatty RA. Vocal cord paralysis associated with anterior cervical fusion: considerations for prevention and treatment. J Neurosurg. 1985;62(5):657-61.

6. Reid RR, Dutra J, Conley DB, Ondra SL, Dumanian GA. Improved repair of cervical esophageal fistula complicating anterior spinal fusion: free omental flap compared with pectoralis major flap. Report of four cases. J Neurosurg. 2004;100(Suppl 1):66-70.

7. Dakwar E, Uribe JS, Padhya TA, Vale FL. Management of delayed esophageal perforations after anterior cervical spinal surgery. J Neurosurg Spine. 2009;11(3):320-5.

8. Benato ML, Zaninell EM, Graells XS, Sonagli MA. Artrodese cervical anterior em três e quatro níveis com dispositivo intersomático não associado à placa cervical. Coluna/ Columna. 2009:8(2):143-7.

9. Bazaz R, Lee MJ, Yoo JU. Incidence of dysphagia after anterior cervical spine surgery: a prospective study. Spine (Phila Pa 1976). 2002;27(22):2453-8.

10. Jagannathan J, Shaffrey Cl, Oskouian RJ, Dumont AS, Herrold C, Sansur CA, Jane JA. Radiographic and clinical outcomes following single-level anterior cervical discectomy and allograft fusion without plate placement or cervical collar. J Neurosurg Spine. 2008;8:420-8. 